\title{
Effect of using acid whey for marinating chicken breast muscles in organic production
}

\author{
Anna Augustyńska-Prejsnar ${ }^{1 *}$, Małgorzata Ormian', Maciej Kluz², Zofia Sokołowicz' \\ ${ }^{1}$ University of Rzeszow, Faculty of Biology and Agriculture, Department of Animal Production and Poultry Products Evaluation; Poland, \\ ${ }^{2}$ University of Rzeszow, Faculty of Biology and Agriculture, Department of Bioenergetics and Food Analysis; Poland
}

\section{A B S T R A C T}

Currently, there is an increase in the group of consumers looking for poultry products obtained from the organic housing system, who pay attention to the relationship between diet and health. The research material consisted of breast muscles of organic chickens that were marinated for 24 hours with acid marinades: acid whey $(n=30)$ and lemon juice $(n=30)$. Acid whey was used in the study as a new ingredient in comparison to the traditional ingredient of marinades (lemon juice). The control group ( $n=30$ ) were non-marinated breast muscles. The physicochemical parameters (marinade absorption, $\mathrm{pH}$, Water Holding Capacity, colour $\mathrm{L}^{*} \mathrm{a}^{*} \mathrm{~b}^{*}$, shear force, chemical composition) and microbiological (mesophilic aerobic bacteria, Pseudomonas spp., coli group, lactic acid bacteria) ones of breast muscles were evaluated immediately after marinating, as well as after grilling treatment. The sensory evaluation was also conducted. Raw breast muscles marinated using whey, in comparison with those marinated with lemon juice, were characterized by $(p<0,05)$ a higher absorption of the marinade, lower saturation of the redness $\left(a^{*}\right)$, better tenderness measured by the shear force (N) and higher ash content. Also, after heat treatment, marinated breast muscles maintained a better $(p<0,05)$ tenderness and juiciness and higher ash content. The study has shown that acid whey can be used as a new marinade in organic chicken meat marinades, as it causes a reduction in the redness saturation, higher ash content, improvement of tenderness and juiciness and increase in the microbiological safety of the product. The use of acid whey meets the expectations of consumers for the use of natural food additives that have a positive impact on human health.

Keywords: Breast Meat; Lemon Juice; Marinating; Whey; Quality

\section{INTRODUCTION}

Dynamic changes that take place in diet and in terms of quality and health safety requirements of food products cause that consumers are looking for more food from organic production (Castellini et al., 2008; Muhammed et al., 2017). The meat of broilers from organic production is characterized by a higher nutritional value (more protein, less fat, favourable ratio of n-6/n-3 fatty acids), darker colour, as well as better taste, and intense aroma compared with the meat of broiler chicken from intensive breeding (Michalczuk et al., 2017). Moreover, it is characterized by a lower tenderness, which may indicate that the meat should be subjected to a longer heat treatment or marinating process (Gornowicz et al., 2017). The element of poultry carcasses chosen most frequently by consumers who care about their diet is the breast muscle.

Marinating meat has been known for many years. The selection of marinade ingredients and marinating techniques are constantly improved so that the product obtained meets the expectations of consumers. The use of marinades using natural additives may determine the desired taste and flavour profile of the product and beneficial effects on the consumer's health, as well as the originality of the dish (Gök and Bor, 2016). The group of natural additives used includes, for example: natural fruit and vegetable juices, herbs and their extracts, fermented milk beverages, sea salt (Kumar et al., 2017; Stadnik and Stasiak, 2016; Fernadez-Lopez et al., 2004).

Juice of lemon (Citrus limon) is commonly used for culinary purposes around the world. Lemon juice is a source of L-ascorbic acid $(0.52 \mathrm{mg} / 100 \mathrm{~g})$, as well as B group vitamins, beta-carotene, macro and micronutrients and biologically active ingredients, such as essential oils (mainly limonene), bioflavonoids, phytoncides, pectins (Lebiedzińska et al., 2012). It also contains citric acid (5-10\%), sugars (2-3\%), fiber $(3 \%)$ and proteins (1\%). Lemon juice is used as a food

\footnotetext{
${ }^{*}$ Corresponding author:

Anna Augustyńska-Prejsnar, University of Rzeszow, Faculty of Biology and Agriculture, Department of Animal Production and Poultry

Products Evaluation; Poland. E-mail: augusta@ur.edu.pl
}

Received: 12 January 2019; $\quad$ Accepted: 24 March 2019 
preservative, often used for marinating meat to improve the juiciness and tenderness of meat (Murali et al., 2012; Kumar et al., 2017; Ke et al., 2009.

Acid whey is a by-product generated during the production of cottage cheese, that is characterized by nutritional and health-promoting properties, undeveloped. it poses a threat to the environment. It is most often used in the production of animal feed and in the food and pharmaceutical industry. Acid whey has a very high biological value, it contains peptides and proteins, among which the most important are $\alpha$-lactalbumin and $\beta$-lactoglobulin, representing $75 \%$ of all whey proteins. Except their pro-health properties, e.g. anticarcinogenic effect, prevention of muscular atrophy, increasing bone resistance to fractures and immuneenhancing properties (Smithers, 2008; Ferysiuk et al., 2018), acid whey proteins have also strong antimicrobial and antioxidant effects (Chatterton et al., 2006). Whey contains high amounts of B-group vitamins (especially vitamin B2) and vitamin A, significant amounts of tryptophan (serotonin precursor) and cysteine (glutathione precursor) and mineral compounds. Acid whey is currently used in functional food production and enjoys the interest of the meat industry, especially in the production of organic meat products. A limited amount of research has been conducted looking at acid whey as a processing additive in meat products. According to the latest research, the use of acid whey for marinated beef improves tenderness and juiciness (Kim, 2018) and colour stability in the baked product and has an antioxidant effect (Wójciak et al., 2018); improves physicochemical properties (Ferysiuk et al., 2018) and limits oxidation of lipids in fermented sausages (Karwowska et al., 2015). Wójciak et al. (2014) used acid whey with mustard seed to replace nitrites in cooked sausages, with positive effects. Stadnik and Stasiak (2016) reported on the physicochemical properties of pork loin marinated in acid whey prior to dry curing. The acid whey marination, combined with sea salt, resulted in reduced browning and was protective against oxidation. Wójciak et al. (2015) explored the use of acid whey as a marinade for production of fermented beef eye of round. They found that acid whey decreased the $\mathrm{pH}$, increased the red colour value as well as oxidative stability. Vlahova-Vangelova et al. (2016) showed the beneficial effect of marinating with whey on the organoleptic characteristics (smell and consistency) of broiler chicken meat. The lack of broader information in the scientific literature presenting the use of acid whey for marinating poultry meat prompted the authors to undertake research in this field.

The aim of this study was to evaluate the effect of use of acid whey for marinating chicken breast muscles from organic production and its influence on quality parameters and product safety.

\section{MATERIAL AND METHODS}

\section{Raw material for the study}

The raw material for the study was breast muscles (musculus pectoralis) obtained from 82-day-old slaughter chickens raised on a farm holding the Certificate of Conformity of Organic Food Production. Chickens were kept in littercovered areas, with access to a green paddock in accordance with the requirements of organic farming, specified in EU legal acts (Commission Regulation EC No 889/2008 and No 834/2007). 24 hours after slaughter, skinless breast muscles were manually cut out of chilled carcasses (45 pieces) (Ziołecki and Doruchowski, 1989). Single breast muscles were used in the study. Meat samples were divided into two groups: non-marinated and marinated. Nonmarinated breast muscles (control group; $\mathrm{n}=30$ ) were stored in air conditions $\left(4^{\circ} \mathrm{C}\right)$. Before marinating the muscles were weighed with an accuracy of $0.01 \mathrm{~g}$ and marked individually.

\section{Preparation of marinade solution}

Two acidic marinades were used in the study. They were prepared based on whey (WM group), comparatively to lemon juice (LJM group). Marinades were supplemented with sea salt $(1.0 \%)$, cane sugar $(1.0 \%)$ and in the LJM group, with distilled water. The concentration of lemon juice is designed to correspond to the average $\mathrm{pH}$ concentration $(4.53 \pm 0.21)$ of acid whey. The marinades were prepared for 1 hour before use and stored at $4^{\circ} \mathrm{C}$. The acid whey came from a local producer of organic curd. Analysis of the whey chemical composition was performed with the Analyzer of the Chemical Composition of Milk and Milk Products, Bentley B-150 (Bentley, USA). For this purpose, the whey was thoroughly mixed in a water bath at $40^{\circ} \mathrm{C}$, the determination was made on the "whey" calibration in three replications. The whey contained $0.86 \%$ protein; $0.19 \%$ fat; $5.12 \%$ lactose and $7.17 \%$ dry matter. Fresh biolemon juice was used ( $\mathrm{pH} 2.46 \pm 0.32$ ) that was squeezed by hand. For this purpose, the fruits were scalded ( 3 minutes in boiling water), cut with a sterile knife and filtered. Sea salt and cane sugar were purchased at the organic food store.

\section{Marinating process}

The process of marinating consisted of immersion of breast muscles - WM group ( $\mathrm{n}=30)$ and LJM group $(\mathrm{n}=30)$ in the prepared marinade. The ratio of meat to marinade was set at 1: 1 (meat: marinade). Samples from the WM and LJM groups were placed in sealed plastic containers and stored in a refrigerator for 24 hours at $4^{\circ} \mathrm{C}$. After the fixed marinating period, the samples were weighed with an accuracy of $0.01 \mathrm{~g}$.

\section{Samples cooking}

Non-marinated (control) and marinated ((W) and (LJM)) breast muscles were subjected to grilling treatment in a 
fat-free grill pan with no fat until the temperature inside a sample reached $80^{\circ} \mathrm{C} \pm 2^{\circ} \mathrm{C}$.

\section{Quality parameters}

\section{Assessment of physicochemical characteristics}

To determine the marinade absorption, control and marinated meat samples were weighed before and after marinating. The marinade absorption was calculated as: Marinade absorption (\%) = weight of sample after marinating $(\mathrm{g})$ - weight of sample before marinating $(\mathrm{g})$ $\mathrm{x} 100 /$ weight of sample before marinating $(\mathrm{g})$. The $\mathrm{pH}$ measurements were achieved using a dagger electrode, fitted with a (HI 99163 from Hanna, Germany) pH meter. The sample water holding capacity (WHC) was determined using the Grau and Hamm (1953) method. The reading of the measurement results was achieved in a CIE LAB colorimetric system CIE LAB (CIE 1978).

\section{Microbiological analysis}

An amount of $10 \mathrm{~g}\left(10 \mathrm{~cm}^{2}\right)$ of the breast muscles was sampled using sterile scalpels and forceps, immediately transferred into a sterile stomacher bag, containing $90 \mathrm{~mL}$ of $0.1 \%$ peptone water ( $\mathrm{pH} 7.0)$, and homogenized for $60 \mathrm{~s}$ in a stomacher at the room temperature. Microbiological analyses were conducted using standard microbiological methods. Anaerobic plate count (AC) was determined using Plate Count Agar (PCA, Oxoid, UK) after incubation for $48 \mathrm{~h}$ at $35^{\circ} \mathrm{C}$ under aerobic conditions. For Pseudomonas spp., $0.1 \mathrm{ml}$ from serial dilutions of meat samples homogenates was spread onto the surface of Pseudomonas Isolation agar (PIA, Oxoid, UK). Pseudomonas spp. were enumerated after incubation for $48 \mathrm{~h}$ at $25^{\circ} \mathrm{C}$. For lactic acid bacteria, Rogosa and Sharpe agar (MRS, Oxoid, UK) was inoculated with a $1.0 \mathrm{ml}$ of sample suspension. Inoculated plates were incubated for $48-78 \mathrm{~h}$ at $37^{\circ} \mathrm{C}$ in an aerobic atmosphere supplemented with carbon dioxide $\left(5 \% \mathrm{CO}_{2}\right)$. For Enterobacteriaceae, a $1.0 \mathrm{ml}$ of sample was transferred into $10 \mathrm{ml}$ of molten $\left(45^{\circ} \mathrm{C}\right)$ Violet Red Bile Glucose agar (VRBL, Oxoid, UK). Inoculated plates were incubated at $37^{\circ} \mathrm{C}$ for $24 \mathrm{~h}$. All plates were examined for typical colony types and morphology characteristics associated with each medium applied for incubation. Enumeration of all tested groups of bacteria was performed in triplicate.

\section{Sensory assessment}

The sensory assessment of the quality of grilled meat samples was conducted using the scaling method according to Baryłko-Pikielna and Matuszewska (2009) methodology. A 5-point evaluation was applied with a defined value limit, including the following qualitative indices: odour intensity (very negative - typical, very strong), flavour intensity (very negative, very sour- typical, very desirable), odour desirability (not desirable- highly desirable), flavour desirability (not desirable- highly desirable), juiciness (very dry- very juicy), tenderness (very hard-very tender) and general desirability (undesirable-desirable). In order to conduct the sensory assessment, the thermally treated samples were cooled to $20^{\circ} \mathrm{C} \pm 2^{\circ} \mathrm{C}$, cut into $1.5 \mathrm{~cm}$ thick slices, perpendicular to the run of meat fibres, and then placed in plastic containers. The samples were randomly assessed after they had been encoded. The sensory assessment process was conducted in two replications, by a 7 -member assessment team with proven sensory sensitivity, trained in accordance with ISO 8586: 2012 and ISO 8587:2006 standards. All the evaluations were performed at a sensory laboratory that conformed to all the requirements of the relevant standard (PN-EN ISO 8589:2010).

\section{Statistical analysis}

Results obtained were statistically analysed with the analysis of variance ANOVA using the Statistica 13.1 software package (StatSoft, Inc. 2018). The arithmetic mean (g) and standard deviation (SD) were determined. To indicate the significance of differences between means in groups, the Tukey's post hoc test with a level of significance $\mathrm{p}<$ (0.05) was applied.

\section{RESULTS AND DISCUSSIONS}

The percent marinade absorption significantly $(p<0.05)$ differed among the treatments. Marinade absorption was observed to be highest for WM and lowest for LJM of all the treatments and the difference might be due to differences in osmotic pressure exerted by different marinade solutions (Table 1). The obtained results are in line with the results of the study by Kumar et al. (2017) for breast muscles of hens after the laying period marinated with lemon juice. Serdaroğlu et al. (2007) obtained a higher absorption of the marinade, using grapefruit juice and citric acid for marinating turkey breast. The degree of acidification of the muscle tissue affects the technological and sensory characteristics of meat, as well as the development of microflora and the intensity of autolytic processes and, consequently, the processing value of meat. The results of studies by many authors (Ergezer and Goke, 2011; Kumar et al., 2015; Kumar et al., 2017; Yusop et al., 2010; Serdaroğlu et al., 2007) show that the $\mathrm{pH}$ of marinated meat depends on the $\mathrm{pH}$ of the marinade, which was confirmed in the present author's study (Table 1). The study by Kumar et al. (2017) indicated that the low meat $\mathrm{pH}$ after marination has positive effects on the texture, increasing the water holding capacity and the moisture content. However, citric acid can reduce $\mathrm{pH}$ to the point where the meat has excessively sour flavours that can cause consumer rejection (Ke et al., 2009). 
In the present study it was shown that marinating using whey (WM) and lemon juice (LJM) significantly $(\mathrm{p}<0.05)$ affected the increase in muscle water holding capacity as compared with the control group; however, no differences were found $(p>0.05)$ in the ability of meat to retain its own water between WM and LJM groups. Increase in the moisture content might be attributed to marinade absorption. Similar results were obtained by Kumar et al. (2015) and Kumar et al. (2017) for breast muscles of hens after the laying period marinated with the use of lemon juice. Meat with a higher water holding capacity loses less meat juice during heat processing, which results in a better juiciness (Yusop et al., 2010).

The colour of marinated meat is related to the colour of meat before marinating and additionally depends on the composition and $\mathrm{pH}$ of the marinade. In the present authors' study, it was shown that marinating using whey (WM) as well as lemon juice (LJM) significantly ( $p<0.05$ ) affected brightening of the colour of both raw breast muscles (Table 1) and those subjected to the grilling process (Table 2) as compared with the control group. Brightening of the colour of breast muscles subjected to marinating results from a greater amount of extracellular water introduced into the meat during marinating and lowering its $\mathrm{pH}$. The obtained results are consistent with the results of the study by Serdaroğlu et al. (2007). According to those researchers, one possible reason for increased $\mathrm{L}^{*}$ values is that muscle proteins swell up and light reflection alters at low $\mathrm{pH}$ and ionic strength, resulting in a lighter colour. The present study showed the influence $(\mathrm{p}<0.05)$ of marinating with the use of whey on the degree of redness saturation of the breast muscle (Table 1 and Table 2). Vlahova - Vangelova (2016) reports that the use of whey for marinating breast muscles of broiler chickens did not affect the colour of the surface in raw and grilled meat. The studies showed that the use of acid marinades affected a reduction in the degree of the yellow colour saturation of raw breast muscles ( $\left.b^{*}\right)$ as compared with the control group (Table 1). It was shown that after heat treatment the muscles marinated with lemon juice were characterized by a significantly $(p<0.05)$ lower degree of yellow colour saturation compared with the control group and marinating with the use of whey (Table 2).

Meat tenderness is one of the most important charracteristics determining quality and consumer acceptance. Many studies (Ergezer and Gokce, 2011; Ke et al. 2009, Kim 2018, Kumar et al., 2017; Serdaroğlu et al., 2006; Wójciak et al., 2015) have indicated that the low meat $\mathrm{pH}$ after marination has positive effects on the texture. The present study indicated a significant $(\mathrm{p}<0.05)$ effect of the applied marinating additives on the tenderness of both raw breast muscles and those subjected to heat treatment (Table 1
Table 1: Physicochemical composition of non-marinated and marinated raw breast muscles

\begin{tabular}{lcccc}
\hline Parameter & Control & \multicolumn{2}{c}{ Marinated } & \\
\cline { 3 - 4 } & & WM & LJM & SEM \\
\hline Marinade & - & $11,10^{\mathrm{a}} \pm 0,24$ & $10,08^{\mathrm{c}} \pm 0,16$ & 0,04 \\
absorption (\%) & & & & \\
pH & $5,84^{\mathrm{a}} \pm 0,08$ & $5,65^{\mathrm{b}} \pm 0,16$ & $5,68^{\mathrm{b}} \pm 0,11$ & 0,02 \\
Water Holding & $39,30^{\mathrm{b}} \pm 0,49$ & $42,01^{\mathrm{a}} \pm 0,94$ & $41,90^{\mathrm{a}} \pm 0,83$ & 0,13 \\
Capacity (\%) & & & & \\
Colour & & & & \\
$\quad$ L $^{*}$ lightness & $55,65^{\mathrm{b}} \pm 3,01$ & $7,20^{\mathrm{a}} \pm 3,42$ & $57,23^{\mathrm{a}} \pm 3,02$ & 0,44 \\
a $^{*}$ redness & $3,34^{\mathrm{a}} \pm 0,79$ & $1,56^{\mathrm{c}} \pm 0,30$ & $2,08^{\mathrm{b}} \pm 0,37$ & 0,10 \\
$\mathrm{~b}^{*}$ - yellowness & $6,50^{\mathrm{a}} \pm 0,93$ & $6,10^{\mathrm{b}} \pm 1,05$ & $5,06^{\mathrm{b}} \pm 1,01$ & 0,12 \\
Shear force (N) & $24,56^{\mathrm{a}} \pm 4,02$ & $17,85^{\mathrm{c}} \pm 6,10$ & $19,60^{\mathrm{b}} \pm 4,22$ & 0,43 \\
Crude protein (\%) & $24,65^{\mathrm{a}} \pm 1,59$ & $22,48^{\mathrm{b}} \pm 1,22$ & $22,24^{\mathrm{b}} \pm 0,40$ & 0,14 \\
Fat (\%) & $0,76^{\mathrm{a}} \pm 0,25$ & $0,54^{\mathrm{b}} \pm 0,19$ & $0,55^{\mathrm{b}} \pm 0,16$ & 0,08 \\
Ash (\%) & $1,35^{\mathrm{c}} \pm 0,09$ & $1,42^{\mathrm{a}} \pm 0,32$ & $1,39^{\mathrm{b}} \pm 0,22$ & 0,02 \\
\hline
\end{tabular}

Explanations: $(\overline{\mathrm{x}} \pm \mathrm{S})$ arithmetic mean \pm standard deviation, WM $(n=10)$, LJM $(n=10)$

$a, b, c$ - values in rows with different letters differ significantly $p<0.05$

Table 2: Physicochemical composition of non-marinated and marinated grilled breast muscles

\begin{tabular}{lcccc}
\hline Parameter & Control & \multicolumn{2}{c}{ Marinated } & \\
\cline { 3 - 4 } & & WM & LJM & SEM \\
\hline pH & $6,23^{\mathrm{a}} \pm 0,10$ & $5,98^{\mathrm{b}} \pm 0,07$ & $6,10^{\mathrm{b}} \pm 0,10$ & 0,08 \\
Colour: & & & & \\
$\mathrm{L}^{*}$ - lightness & $82,17^{\mathrm{b}} \pm 1,65$ & $84,11^{\mathrm{a}} \pm 2,12$ & $84,29^{\mathrm{a}} \pm 1,93$ & 0,39 \\
$\mathrm{a}^{*}$ - redness & $2,21^{\mathrm{a}} \pm 0,23$ & $1,98^{\mathrm{b}} \pm 0,46$ & $2,13^{\mathrm{a}} \pm 0,52$ & 0,09 \\
$\mathrm{~b}^{*}$ - yellowness & $12,72^{\mathrm{a}} \pm 0,84$ & $12,79^{\mathrm{a}} \pm 1,06$ & $10,46^{\mathrm{b}} \pm 0,58$ & 0,16 \\
Shear force (N) & $28,43^{\mathrm{a}} \pm 6,73$ & $22,49^{\mathrm{c}} \pm 5,45$ & $23,52^{\mathrm{b}} \pm 3,01$ & 0,32 \\
Crude protein (\%) & $31,07^{\mathrm{a}} \pm 1,53$ & $30,01^{\mathrm{b}} \pm 1,22$ & $29,96^{\mathrm{b}} \pm 1,23$ & 0,23 \\
Fat (\%) & $1,10^{\mathrm{a}} \pm 0,12$ & $0,84^{\mathrm{b}} \pm 0,38$ & $0,82^{\mathrm{b}} \pm 0,41$ & 0,07 \\
Ash (\%) & $1,42^{\mathrm{c}} \pm 0,21$ & $1,51^{\mathrm{a}} \pm 0,11$ & $1,47^{\mathrm{b}} \pm 0,13$ & 0,12 \\
Weight loss (\%) & $20,45^{\mathrm{a}} \pm 1,83$ & $18,82^{\mathrm{b}} \pm 2,41$ & $18,12^{\mathrm{b}} \pm 2,14$ & 0,21 \\
\hline
\end{tabular}

Explanations: $(\bar{x} \pm s)$ arithmetic mean \pm standard deviation, WM $(n=10)$, LJM $(\mathrm{n}=10)$

a, b, c - values in rows with different letters differ significantly $p<0.05$

and Table 2). Breast muscles marinated with the use of whey were characterized by the smallest $(\mathrm{p}<0.05)$ cutting force (F max). The mechanism of the tenderising effect of acidic marinades involves the weakening of structures due to swelling of meat and increased conversion of collagen to gelatin at low pH during cooking (Berge et al., 2001). The acid breaks the transversal bounds of collagen, leading to the unstable structure loss of this connective tissue protein (Kumar et al., 2017; Wójciak et al., 2018). The results obtained by Ergezer and Gokce (2011) showed that the use of lactic acid for marinating turkey breast muscles decreased the value of cutting force as compared with the control.

The study showed a significant effect of marinating on the chemical composition of breast muscles, both raw as well as processed by grilling (Table 1 and Table 2). The marinating process reduced the protein content, which could be due to an increased moisture content. Further it could also be attributed to degradation of collagen and myofibrillar 
proteins by the action of citric acid. The reduction in the fat content could be due to the absorption of the marinade solution. The obtained results are similar to those obtained by Kumar et al. (2017). Different results were obtained by Hong et al. (2016) marinating breast muscles of broiler chickens with lime juice. In the present study, significant $(p<0.05)$ differences in ash content were found both in raw breast muscles and after heat treatment between marinating treatments. The lowest ash content was demonstrated in the control group, the highest in the group marinated using whey (WM). The increase in ash content was probably caused by a higher ability to retain own water in raw breast muscles and a smaller leakage of meat during thermal treatment and thus a smaller loss of minerals.

In the study it was shown that the used acidic marinades were effective in inhibiting an increase in the number of mesophilic aerobic bacteria in raw breast muscles (Table 3). The antimicrobial effects of organic acids, such as citric acid and lactic acid, is due to both a decrease in $\mathrm{pH}$ below the growth range and metabolic inhibition by undissociated acid molecules (Alvarado and McKee, 2007). The highest number of mesophilic aerobic bacteria was found in the control group (3.51 log cfu.g-1). The breast muscles marinated using lemon juice (2.80 log cfu.g-1) were characterized by a significantly $(\mathrm{p}<0.05)$ lower number of aerobic bacteria as compared with those marinated with whey (3.16 log cfu.g-1). The obtained results of the study for muscles marinated using lemon juice are confirmed in the study by Lytou et al. (2018). Marinating using both whey (WM) and lemon juice (JLM) caused $(p<0.05)$ a decrease in logarithmic units in the initial population of Psendomonas spp. Also in the studies of Lytou et al (2018), it was shown that acidic fruit marinades reduced the number of Psendomonas spp bacteria compared to the control group. From the microbiological perspective, the antimicrobial substances contained in acid whey and lemon juice, such as organic acids, whey protein, bacteriocins and polyphenols, were responsible for the inhibition of microbial growth. The $\mathrm{pH}$ reduction caused by organic acids (citric, lactic) was the primary factor that affected the reduction of microorganisms (Ahmad et al., 2017; Alvadaro and Mc Kee 2007; Amini et al., 2017). In the present study it was shown that after thermal treatment no aerobic bacteria were found in both the control group and in WM and LJM. During the incubation, no bacteria from the group Psendomonas spp. as well as the coli group were found in the raw chicken breast muscles both in the control group and after the marinating process (Table 3), which indicates a good quality of the initial product.

It was shown that marinating chicken muscles using whey significantly $(p<0.05)$ increased the number of lactic acid bacteria compared with the control and marinating using lemon juice (Table 3). Similar results were obtained by Wójciak et al. (2014) and Wójciak et al. (2015) in a pork and beef product marinated in whey with the addition of sea salt. According to Wójciak et al. (2014), an addition of sea salt contributes to the growth of lactic acid bacteria in a meat product marinated with whey. Vlahova - Vangelova (2016) proved in her study that the acid whey concentration and marinating time had an impact on increasing the population of lactic acid bacteria in raw breast muscles of broiler chickens. According to Dolatowski (2011), a high number of lactic acid bacteria in meat products guarantees microbiological stability and the safety of an organic product. In the present authors' study, it was shown that no lactic acid bacteria were found after heat treatment of breast muscles.

Apart from preserving, margination affects the sensory characteristics of meat (Kim 2018). The study showed that marinating with the use of acid marinades improved the acceptability of sensory characteristics of breast muscles compared with the control (Table 4). In consumer assessment, the important parameters of meat quality after heat treatment are juiciness and tenderness. It was demonstrated that the breast muscles of organic production chickens marinated using whey (WM) were characterized by a better juiciness and tenderness as compared with those marinated using lemon juice (LJM) and from the control group. According to Serdaroğlu et al. (2007), acid marinades increase the juiciness and

Table 3: Microbiologial composition of non-marinated and marinated raw breast muscles

\begin{tabular}{lcccc}
\hline $\begin{array}{l}\text { Parameter } \\
\text { (log cfu.g }^{-1} \text { ) }\end{array}$ & Control & \multicolumn{2}{c}{ Marinated } & \\
\cline { 3 - 4 } & & WM & LJM & SEM \\
\hline $\begin{array}{l}\text { Mesophilic aerobic } \\
\text { bacteria }\end{array}$ & $3,51^{\mathrm{a}} \pm 0,24$ & $3,16^{\mathrm{b}} \pm 0,29$ & $2,80^{\mathrm{c}} \pm 0,25$ & 0,09 \\
Pseudomonas spp. & $3,26^{\mathrm{b}} \pm 0,00$ & $2,62^{\mathrm{a}} \pm 0,00$ & $2,56^{\mathrm{a}} \pm 0,00$ & 0,04 \\
Coli group bacteria & $0,00 \pm 0,00$ & $0,00 \pm 0,00$ & $0,00 \pm 0,00$ & 0,00 \\
Lactic acid bacteria & $3,02^{\mathrm{a}} \pm 0,10$ & $3,56^{\mathrm{b}} \pm 0,15$ & $3,00^{\mathrm{a}} \pm 0,12$ & 0,08 \\
\hline
\end{tabular}

Explanations: $(\bar{x} \pm s)$ arithmetic mean \pm standard deviation, $W M(n=10)$, LJM $(n=10)$

a, b, c -values in rows with different letters differ significantly $p<0.05$

Table 4: Sensory properties of non-marinated and marinated grilled breast muscles

\begin{tabular}{lcccc}
\hline Traits & Control & \multicolumn{2}{c}{ Marinated } & \\
\cline { 3 - 4 } (scores) & & WM & LJM & SEM \\
\hline Odour intensity & $4,65^{\mathrm{b}} \pm 0,49$ & $4,86^{\mathrm{a}} \pm 0,00$ & $4,84^{\mathrm{a}} \pm 0,51$ & 0,08 \\
$\begin{array}{l}\text { Flavour intensity } \\
\text { Odour }\end{array}$ & $4,15^{\mathrm{a}} \pm 0,88$ & $4,65^{\mathrm{b}} \pm 0,37$ & $4,70^{\mathrm{b}} \pm 0,46$ & 0,07 \\
$\begin{array}{l}\text { desirability } \\
\text { Flavour }\end{array}$ & $4,55^{\mathrm{b}} \pm 0,51$ & $4,88^{\mathrm{a}} \pm 0,37$ & $4,86^{\mathrm{a}} \pm 0,44$ & 0,07 \\
desirability & $4,05^{\mathrm{c}} \pm 0,76$ & $4,62^{\mathrm{b}} \pm 0,51$ & $4,88^{\mathrm{a}} \pm 0,62$ & 0,07 \\
Juiciness & & & & \\
Tenderness & $3,95^{\mathrm{c}} \pm 0,44$ & $4,80^{\mathrm{a}} \pm 0,31$ & $4,65^{\mathrm{b}} \pm 0,13$ & 0,08 \\
Total desirability & $4,65^{\mathrm{c}} \pm 0,49$ & $4,90^{\mathrm{a}} \pm 0,31$ & $4,74^{\mathrm{b}} \pm 0,41$ & 0,06 \\
\hline & $4,30^{\mathrm{a}} \pm 0,51$ & $4,78^{\mathrm{b}} \pm 0,37$ & $4,76^{\mathrm{b}} \pm 0,42$ & 0,08 \\
\hline
\end{tabular}

Explanations: $(\bar{x} \pm s)$ arithmetic mean \pm standard deviation, WM $(n=10)$, LJM $(n=10)$

a, b, c -values in rows with different letters differ significantly $p<0.05$ 
tenderness of a product. Vlahova-Vangelova et al. 2016 also indicated the beneficial effect of marinating with whey (50\% whey and $50 \%$ water) on the consistency of grilled broiler chicken meat. Kim (2018) found that the use of acid whey for marinating beef improves the juiciness of a product compared with the control and gives the product a more acceptable taste, resulting from mineral elements and other whey ingredients. In the present authors' study, it was shown that marinating with whey had a positive effect on taste desirability compared with the control, but a higher taste desirability was found in breast muscles marinated using lemon juice (Table 4).

\section{CONCLUSION}

The study has indicated the beneficial effect of the marinating process using WM and LJM acid marinades on the quality characteristics (increasing water holding capacity, brightening of colour, increasing tenderness measured by cutting force, reducing fat content and increasing ash content, increasing microbiological safety and reducing losses after heat treatment) of both raw as well as grilled chicken breasts from organic farming.

Raw breast muscles marinated using whey, in comparison with those marinated with lemon juice, were characterized by a higher absorption of the marinade, lower saturation of the redness, better tenderness measured by the cutting force and higher ash content. Also, after heat treatment, marinated breast muscles maintained a better tenderness and juiciness and a higher ash content. The results of the study suggest that acid whey can be used as a new ingredient in marinades for the meat of chickens from organic production, providing a basis for further research on its use in marinating poultry meat.

\section{CONFLICT OF INTEREST}

The authors declare that there is no conflict of interest.

\section{Author contributions}

A. A.-P. made the conception and design of research, analysed and interpretated of data, drafed the article.; M.O. performed the research and participated in article drafting; M.K. made microbiological analisis; Z.S. revised article for important substantive content; All the authors have read and made approval of the final version of the manuscript.

\section{REFERENCES}

Ahmad, Z., S. S. Hassan and S. Azim. 2017. A therapeutic connection between dietary phytochemicals and ATP synthase. Curr. Med. Chem. 24: 3894-3906.
Alvarado, C. and S. McKee. 2007. Marination to improve functional properties and safety of poultry meat. J. App. Poult. Res. 16(1): 113-120.

Amini, A., M. Liu and Z. Ahmad. 2017. Understanding the link between antimicrobial properties of dietary olive phenolics and bacterial ATP synthase. Int. J. Biol. Macromol. 101: 153-164.

Baryłko-Pikielna, N. and I. Matuszewska. 2009. Sensory Testing of Food. Basics Methods Application. Publishing: Polish Society of Food Technologists.

Berge, P., P. Ertbjerg, L. M. Larson, T. Astruc, X. Vignon and A. J. Moller. 2001. Tendeization of beef lactic acid injected at different times post mortem. Meat Sci. 57: 347-357.

Castellini, C., C. Berri, E. LeBihan-Duval and G. Martino. 2008. Qualitative attributes and cconsumer perception of organic and free-range poultry meat. Worlds Poult. Sci. J. 65: 120-135.

Chatterton, D. W. E., G. Smithers, P. Roupas and A. Brodkorb. 2006. Bioactivity of b-lactoglobulin and a-lactalbumin-Technological implications for processing. Int. Dairy J. 16: 1229-1240.

Commission Regulation. 2008. Commission Regulation (EC) No 889/2008 of 5 September 2008 Laying Down Detailed Rules for the Implementation of Council Regulation (EC) No 834/2007 on Organic Production and Labelling of Organic Products with Regard to Organic Production, Labelling and Control.

Council Regulation. 2007. Council Regulation (EC) No 834/2007 of 28 June 2007 on organic Production and Labelling of Organic Products and Repealing Regulation (EEC) No 2092/91.

Dolatowski, Z. 2017. Processing Innovative Solutions in the Field of Processing to Increase Health Values Organic Product of Plant and Animal Products Ecological Methods: Research on Optimization and Development. Report on Research for Organic Farming Financed by the Ministry of Agriculture and Rural Development.

Ergezer, H. and R. Gokce. 2011. Comparison of marinating with two different types of marinade on some quality and sensory characteristics of turkey breast meat. J. Anim. Vet. Adv. 10(1): 60-67.

Grau, R. and R. Hamm. 1953. Eine einfache methode zur bestimmung der wasserbindung im muskel. Naturwiss 40: 29-30.

Gornowicz, E., M. Pietrzak, D. Stanisławski, R. Steppa, L. Lewko and A. Kryza. 2017. Meat quality characteristics of chickens raised organically and intensively. Rocz. Nauk. Pol. Towarzystwa Zootech 13(3): 33-41.

Fernández-López, J., J. M. Fernández-Ginés, L. Aleson-Carbonell, E. Sendra, E. Sayas-Barberá and J. A. Pérez-Alvarez. 2004. Application of functional citrus by-products to meat products. Trends Food Sci. Technol. 15: 176-185.

Ferysiuk, K., K. Wójciak and E. Solska. 2018. Effect of acid whey as starter culture on selected physicochemical properties of fermented pork sausage. World Sci News 93: 23-31.

Gök V. and Y. Bor. 2016. Effect of marination with fruit and vegetable juice on the some quality characteristics of turkey breast meat. Braz. J. Poult. Sci. 18(3): 481-488.

Hong, G. E., P. K. Mandal, J. H. Kim, W. J. Park, J. W. Oh, K. W. Lim and C. H. Lee. 2016. Influence of lime juice on the pink discoloration and quality of sous-vide processed chicken breast during refrigerated storage. J. Food Qual. 39(6): 726-731.

ISO. 2006. IOS 8587 Sensory Analysis. Methodology. Ranking. International Organization for Standardization, Geneva.

ISO. 2012. ISO 8586 Sensory Analysis. General Guidelines for the Selection, Training and Monitoring of Selected Assessors and Expert Sensory Assessors, International Organization for Standardization, Geneva. 
Karwowska, M., K. M. Wójciak and Z. J. Dolatowski. 2015. The influence of acid whey and mustard seed on lipid oxidation of organic fermented sausage without nitrite. J. Sci. Food Agric. 95: 628-634.

Ke, S., Y. Huang, E. A. Decker, P. Hultin and P. P. Purslow. 2009. Impact of citric on the tenderness, microstructure and oxidative stability of beef muscle. Meat Sci. 82: 113-118.

Kim J. 2018. Effects of acid whey marination on tenderness, sensory and other quality parameters of beef eye of round. Brigham Young University BYU Scholars Archive.

Kumar, Y., P. Singh, V. K. Tanwar, P. Ponnusamy, P. K. Singh and P. Shukla. 2015. Augmentation of quality attributes of chicken tikka prepared from spent hen meat with lemon juice and ginger extract marination. Nutrition and Food Science 45: 606-615.

Kumar, Y., P. Singh, A. Pandey, V. Kumar Tanwar and R. R. Kumor. 2017. Augumentation of meat quality attributes of spent hen breast muscle (Pectoralis Major) by marination with lemon juice vis-a-vis ginger extract. J. Anim. Res. 7(3): 523-529.

Lebiedzińska, A., J. Czaja, K. Petrykowska and P. Szefer. 2012. Evaluation of Vitamin $\mathrm{c}$ content in fruit juices and nectars. Bromatol. Chem. Toksyk. 3: 390-396.

Lutou, A. E, G. J. E. Nychas and Z. Panagou. 2018. Effect of pomegranate based marinades on the microbiological, chemical and sensory quality of chicken meat: A metabolomics approach. Int. J. Food Microbiol. 267: 42-53.

Michalczuk, M., Ż. Zdanowska-Sąsiadek, K. Damaziak and J. Niemiec. 2017. Influence of indoor and outdoor on meat quality of slowgrowing chickens. CYTA J. Food 15(1): 15-20.

Muhammed, I. K., F. K. Faisal, M. Majid, U. K. Mohammad, M. Ali, N. Pimenov, I. Pigorev, A. Glinushkin and A. Laishevtcev. 2017. Free range poultry husbandry and physiochemical quality of meat: A review. Int. J. Res. Ayurveda Pharm. 8: 74-79.

Murali, N., N. C. Kumar-Philips, J. Marcy and M. F. Slavik. 2012. Effect of marinating chicken meat with lemon, green tea and turmeric against foodborne bacterial pathogens. Int. J. Poult. Sci. 11(5): 326-332.
PN-EN ISO 8589:2010. General Guidelines for the Design of a Sensory Analysis Laboratory. International Organization for Standardization, Geneva.

Serdaroğlu, M., K. Abdraimov and A. Önec. 2007. The effect of marinating with citric acid solutions and grapefruit juice on cooking and eating quality of turkey breast. J. Muscle Foods 18: 162-172.

Smithers, G. W. 2008. Whey and whey proteins -From gutter-to-gold. Int. Dairy J. 18: 695-704.

Stadnik, J. and D. M. Stasiak. 2016. Effect of acid whey on physicochemical characteristics of dry-cured organic pork loins without nitrite. Int. J. Food Sci. Tech. 51(4): 970-977.

Statsoft, Inc. Statistica (data analysis sofware system system) Veriosion 31.1. 2018.

Wójciak, K. M., M. Karwowska and Z. J. Dolatowski. 2014. Use of acid whey and mustard seed to replace nitrites during cooked sausage production. Meat Sci. 96(2): 750-756.

Wójciak, K. M., P. Krajmas, E. Solska and Z. J. Dolatowski. 2015. Application of acid whey and set milk to marinate beef with reference to quality parameters and product safety. Acta Sci. Pol. Technol. Aliment. 14(4): 293-302.

Wójciak, K. M., P. Kęska, A. Okoń, E. Solska, J. Libera and Z. J. Dolatowski. 2018. The influence of acid whey on the antioxidant peptides generated to reduce oxidation and improve colour stability in uncured roast beef. J. Sci. Food Agric. 98: 3728-3734.

Vlahova-Vangelova, D. B., D. K. Balev, S. G. Dragoev and G.D. Kirisheva. 2016. Improvement of technological and sensory properties of meat by whey marinating. Scientific Works of University of Food Technologies 63(1): 7-13.

Yusop, S. M., M. G. O Sullivan, J. F. Kerry and J. P. Kerry. 2010. Effect of marinating time and low $\mathrm{pH}$ on marinade performance and sensory acceptability of poultry meat. Meat Sci. 85: 657-663.

Ziołecki, J. and W. Doruchowski. 1989. Evaluation Method of the Poultry Slaughter Value. Publishing COBRD, Poznań. 